\title{
MODEL PENINGKATAN KEPUTUSAN KONSUMEN MELALUI KUALITAS PRODUK, 156 HARGA DAN FOOD SAFETY UMKM IKAN ASIN PANIMBANGAN BANTEN
}

\author{
Soehardi'; Rini Wijayaningsih²; Jumawan3; Widi Winarso4; M Fadhli Nursal5; Adi \\ Wibowo Noor Fikri6 \\ Universitas Bhayangkara Jakarta Raya ${ }^{1,2,3,4,5}$
}

soehardi@dsn.ubharajaya.ac.id ${ }^{1}$; rini.wijayaningsih@dsn.ubharajaya.ac.id²; jumawan@dsn.ubharajaya.ac.id33; widi.winarso@dsn.ubharajaya.ac.id4; fadhli.nursal@dsn.ubharajaya.ac.id5; adi.noor@dsn.ubharajaya.ac.id5

\begin{abstract}
ABSTRAK
Tujuan penelitian ini adalah untuk menganalisis model peningkatan keputusan konsumen melalui kualitas produksi, harga dan food safety UMUKM ikan asin Panimbang Provinsi Banten. Populasi dalam penelitian ini adalah seluruh karyawan yang bekerja pada usaha mikro, kecil dan menengah di Kecamatan Panimbang Provinsi Banten. Sampel yang digunakan dalam penelitian adalah purposive sampling dengan jumlah 95 orang. Penelitian ini menggunakan metode penelitian kuantitatif dengan analisis uji validitas, reliabilitas, normalitas, uji t, uji $\mathrm{F}$ dan koefisien determinasi. Keputusan konsumen dipengaruhi secara signifikan oleh kualitas produk. Rasa produk ikan asin lebih disukai dari pada warna, bau dan metode proses ikan asin. Keputusan konsumen dipengaruhi secara signifikan oleh Harga. Biaya pembelian bahan baku merupakan faktor penting bagi pengain apabila dibandingkan biaya tenaga kerja dan persaingan harga. Keputusan konsumen dipengaruhi secara signifikan oleh food safety. Tidak adanya label food safety produk ikan asin Panimbang menjadi faktor yang dominan dibandingkan kontaminasi bahan-bahan kimia, garam dan mikroba. Semakin baik kualitas produk, persaingan harga kompetitif dan aman dari kontamina, maka semakin tinggi keputusan konsumen untuk membeli produk ikan teri Panimbang Banten. Keputusan konsumen untuk membeli ikan asin Panimbang Banten banyak faktor-faktor yang menentukan antara lain: kualitas produk, harga dan food safety. Berdasarkan hasil penelitian diperoleh kualitas produk lebih berpengaruh terahadp keputusan konsumen apabila dibandingkan dengan harga dan food safety.
\end{abstract}

Kata Kunci: Keputusan Konsumen, Kualitas Produk, Harga dan Food Safety

\section{ABSTRACT}

The purpose of this research was to analyze a model for increasing consumer decisions through product quality, price and food safety of salted fish in Panimbang, Banten Province. The population in this study were all employees who worked in micro, small and medium enterprises in Panimbang District, Banten Province. The sample used in the study was purposive sampling with a total of 95 people. This research uses quantitative research methods with analysis of validity, reliability, normality, $t$ test, $f$ test and coefficient of determination. Consumer decisions are significantly influenced by product quality. The taste of the salted fish product is preferred over the color, smell and 
processing method of the salted fish. Consumer decisions are significantly influenced by Price. The cost of purchasing raw materials is an important factor for designing when compared to labor costs and price competition. Consumer decisions are significantly influenced by food safety. The absence of a food safety label for Panimbang salted fish products is a dominant factor compared to contamination of chemicals, salt and microbes. The better the quality of the product, the competitive price competition and food safe from contamination, the higher the consumer's decision to buy anchovies products in Panimbang, Banten. The consumer's decision to buy Panimbang Banten salted fish has many determining factors, including: product quality, price and food safety. Based on the results of the study, it was found that the product quality was more influential on consumer decisions when compared to price and food safety.

Keywords: Consumer Decision, Product Quality, Price and Food Safety

Diterima: 20 September 2021; Direvisi: 30 September 2021; Diterbitkan: Oktober 2021

\section{PENDAHULUAN}

Salah satu Tempat Pelelangan Ikan (TPI) di Indonesia adalah Desa Panimbang Jaya Kecamatan Panimbang Kabupaten Pandeglang Provinsi Banten. Jarak tempuh dari ibukota Jakarta sekitar $181 \mathrm{~km}$. Lokasi ini dapat ditempuh melalui jalan tol Jakarta - Serang dan dilanjutkan dengan jalan raya Serang menuju Kabupaten Serang dan Panimbang Kabupaten Pandeglang. Pemerintah Indonesia sedang giat-giatnya melaksanakan pembangunan jalan tol Serang - Rangkasbitung - Panimbang.

Potensi produk perikanan yang besar ini belum dikembangkan secara maksimal oleh para pelaku usaha mikro, kecil dan menengah seperti belum banyaknya keterlibatan investor dalam negeri dan luar negeri, kemitraan dengan perbankan hanya sebatas pada pinjaman modal usaha dengan bunga dan jaminan baik sertifikat tanah maupun kendaraan bermotor serta pemasaran yang terbatas pada pelanggan dalam negeri yang berasal dari Jakarta, Tangerang, Bogor, Depok dan Bekasi.

Kementerian Kelautan dan Perikanan dan Pemerintah Kabupaten terus berupaya untuk meningkatkan kesejahteraan para nelayan dan karyawan pengelola bisnis UMKM produk perikanan di Kecamatan Panimbang Provinsi Banten. Namun usaha yang telah dilakukan tersebut belum juga meningkatkan pendapatan para nelayan yang mencari ikan di Selat Sunda hingga disekitar perairan Lampung serta para pengasih usaha mikro, kecil dan menangah yang masih jauh dari sejahtera. Kemitraan yang komprehensif berupa Public - Private Partnership belum dilaksanakan secara baik dan benar terlihat dari kurang gencarnya pemerintah Kabupaten Pandeglang dan Pemerintah Provinsi Banten dalam upaya peningkatan pelatihan tentang nilai tambah kualitas produk perikanan serta hibah modal usaha serta international and national marketing kepada para nelayan dan UMK Kecamatan Panimbang.

Keputusan konsumen sangat berbeda-beda yang datang langsung ke tempat-tempat usaha mikro dan kecil Kecamatan Panimbang dan sebagian besar menanyakan tentang kualitas produk, food safety dan membandingkan harga dari UMKM yang satu dengan UMKM yang lainnya. Begitu pula dengan keputusan konsumen ikan asin online dipengaruhi oleh banyaknya pilihan-pilihan online market 
place (tokopedia, shopee, lazada, blibli, dan lain-lain) yang menampilkan beberapa kualitas produk, kualitas pelayanan, desian pengepakan yang menarik dengan warna warni, jaminan produk berkualitas, on time delivery dan harga kompetitif.

\section{LANDASAN TEORI}

\section{Keputusan Konsumen}

(Kotler \& Keller, 2012) Model tradisional proses pengambilan keputusan konsumen "Model lima tahap dari proses pembelian konsumen" (Gambar 2) melibatkan lima langkah yang dilalui konsumen saat membeli produk atau jasa. Seorang pemasar harus memahami langkah-langkah ini untuk menggerakkan konsumen dengan benar untuk membeli produk, berkomunikasi secara efektif dengan konsumen dan menutup penjualan. dalam bukunya mendeskripsikan model ini secara detail dan menjelaskan tahapan tambahan dari tahapan pembuangan model. Juga, mereka membahas efek Moderasi pada pengambilan keputusan konsumen (seperti keterlibatan konsumen).

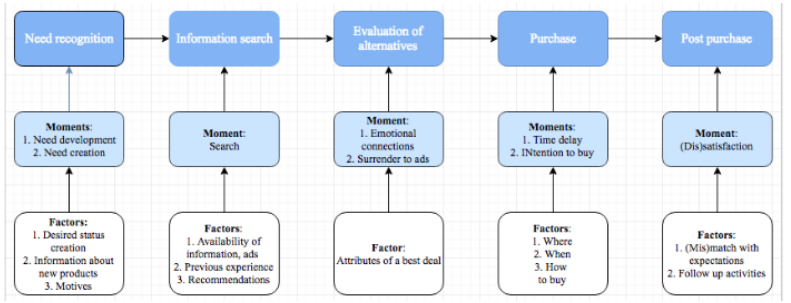

Gambar 1. Faktor-Faktor Yang Mempengaruhi Keputusan Konsumen

(Stankevich, 2017) mengatakan bahwa keputusan konsumen meliputi pengakuan kebutuhan, pencarian informasi evaluasi alternative, pembelian dan pasca pembelian seperti gambar 1 tersebut diatas. (Oke et al., 2016) menyebutkan faktorfaktor yang mempengaruhi keputusan konsumen seperti kenyamanan untuk membeli, racikan bahan baku, rasa, harga, dan pengemasan. Perlu untuk pengembangan riset pemasaran lebih lanjut dan juga strategi perencanaan strategi pemasaran yang efisien dalam menjawab kebutuhan konsumen.

Menurut (Maina \& Ndolo, 2019), faktor-faktor seperti kenyamanan, harga murah, informasi produk, dan waktu meningkatkan keputusan untuk terlibat dalam e-shopping. Belanja online adalah tren yang menarik banyak klien setiap hari. Oleh karena itu, penting untuk menilai hal ini pola agar pembeli dan penjual selalu upto-date dengan mode perdagangan saat ini. Pemahaman ini akan memungkinkan pedagang untuk memenuhi kebutuhan pelanggan, seperti berjualan melalui internet. Pelanggan juga dapat mengetahui faktor-faktor yang dapat mempengaruhi metode tersebut yang mereka gunakan untuk membeli barang, misalnya, melalui cara online atau tradisional.

(Zugravu Gheorghe \& Turek Rahoveanu, Maria Magdalena; Turek Rahoveanu, 2012) Ada dua faktor yang terutama mempengaruhi konsumen dalam pengambilan keputusan: Penghindaran risiko dan inovasi. Penghindaran risiko adalah ukuran seberapa banyak konsumen perlu yakin dan yakin tentang apa yang mereka beli. Konsumen merugikan yang sangat berisiko perlu sangat yakin tentang apa yang mereka beli. Sedangkan konsumen yang merugikan risiko yang lebih kecil dapat mentolerir beberapa risiko dan ketidakpastian dalam pembelian mereka. Variabel kedua, inovasi, adalah ukuran global yang menangkap sejauh mana konsumen bersedia mengambil risiko dan bereksperimen dengan cara-cara baru dalam melakukan sesuatu.

\section{Kualitas Produk}


(Bremner, 2003), sistem jaminan kualitas berdasarkan Hazard Analysis Critical Control Points (HACCP) telah digunakan untuk ikan yang diawetkan dan dikeringkan. Proses ikan asin yang dikeringkan berdasarkan audit HACCP terdiri dari: pendaratan ikan, penyiraman air, pengasinan, pengeringan dan penyimpanan. (Zugravu Gheorghe \& Turek Rahoveanu, Maria Magdalena; Turek Rahoveanu, 2012) mengatakan bahwa secara umum, konsumen akan lebih banyak mengonsumsi produk perikanan dan budidaya jika: ada label yang berkualitas, harga lebih terjangkau dan pengetahuan yang lebih baik tentang kualitas produk perikanan.

(Baldwin \& Harrigan, 2011), kualitas
produk dibedakan dalam model perdagangan dengan perusahaan yang beranekaragam. Perusahaan yang lebih produktif akan menjual harga lebih tinggi dengan kualitas yang lebih tinggi mengacu pada insentif yang relatif lebih besar bahwa perusahaan semacam ini harus melakukan investasi peningkatan kualitas. Perusahaan yang memiliki kualitas produk yang tinggi adalah yang paling kompetitif dengan kualitas produk perusahaan yang beranekaragam dapat meningkatkan biaya pendapatan perusahaan. (Fajgelbaum et al., 2011), konsumen dengan pendapatan dan selera beranekaragam dalam membeli produk dan merek yang sama memiliki pilihan kualitas dan variasi produk yang berbeda. Produk meningkat maka pendapatan pun juga meningkat. Mengapa negara-negara maju memilih produkproduk berkualitas lebih tinggi, hal ini konsekuensinya dalam meningkatkan kesejahteraan dari bisnisnya. (Hidayat et al., 2021)

\section{Harga}

(Kotler \& Keller, 2012) menganalisis Biaya Pesaing, Harga, dan Penawaran dalam kisaran harga yang mungkin ditentukan oleh permintaan pasar dan biaya perusahaan, perusahaan harus memperhitungkan biaya, harga, dan kemungkinan reaksi harga pesaing. Jika perusahaan menawarkan berisi fitur yang tidak ditawarkan oleh pesaing terdekat, harus mengevaluasi nilainya bagi pelanggan dan menambahkan nilai tersebut ke harga pesaing. Jika penawaran pesaing berisi beberapa fitur tidak ditawarkan oleh perusahaan, perusahaan harus mengurangi nilainya dari harganya sendiri. Sekarang perusahaan bias putuskan apakah dapat menagih lebih banyak, sama, atau kurang dari pesaing. Pengenalan atau perubahan harga apa pun dapat memancing tanggapan dari pelanggan, pesaing, distributor, pemasok, dan bahkan pemerintah. Pesaing paling mungkin bereaksi ketika harga perusahaan berubah pada produk homogen. Reaksi pesaing menjadi masalah khusus jika perusahaan ini memiliki proposisi nilai yang kuat.

(Pogorelova et al., 2016) mengatakan bahwa pembentukan harga klasik, yaitu: biaya, konsumen, nilai dan persaingan. (Haghiri, 2016) menjelaskan ketika kualitas makanan dan keamanan makanan menjadi masalah, keputusan konsumen tidak ragu bahwa mereka harus membayar harga premium untuk membeli produk yang aman dan berkualitas tinggi.

Konsumen yang terdiri dari pelanggan tetap dan tidak tetap memegang peranan penting bagi perusahaan untuk terus berusaha meningkatkan persedian pasokan bahan baku produk kopi, kapasitas mesin produksi, biaya tenaga kerja dan strategi pemasaran serta penjualan. Beberapa cara untuk meningkatkan volume penjualan antara lain harga dan kualitas pelayanan 
tenaga pemasaran. Harga bukan hanya ditentukan oleh biaya operasisional, namun juga ditentukan oleh persaingan harga produk dari perusahaan-perusahaan pesaing (Soehardi, 2021).

\section{Food Safety}

(Food and Agriculture Organization, 2020) Istilah food safety dan kualitas terkadang membingungkan. Keamanan pangan mengacu pada semua bahaya tersebut, baik kronis maupun akut, yang dapat membuat makanan berbahaya bagi Kesehatan konsumen. Itu tidak bisa ditawar. Kualitas mencakup semua atribut lain yang mempengaruhi nilai produk kepada konsumen. Ini termasuk atribut negatif seperti pembusukan, kontaminasi dengan kotoran, perubahan warna, bau tidak sedap dan atribut positif seperti asal, warna, rasa, tekstur dan metode pengolahan makanan. Perbedaan antara food safety dan kualitas ini berimplikasi pada kebijakan publik dan mempengaruhi sifat dan isi dari sistem pengendalian pangan yang paling cocok untuk dipenuhi tujuan nasional yang telah ditentukan sebelumnya.

(Iso Indonesia Center, 2018) Keamanan pangan adalah tentang pencegahan, eliminasi dan pengendalian bahaya bawaan makanan, dari tempat produksi hingga titik konsumsi. Karena bahaya keamanan pangan dapat berada pada setiap tahap proses, setiap perusahaan dalam rantai pasokan makanan harus melakukan pengendalian bahaya yang memadai. Bahkan, keamanan pangan hanya dapat dipertahankan melalui upaya gabungan semua pihak: pemerintah, produsen, pengecer, dan konsumen akhir. ISO 22000:2018 ditujukan untuk semua organisasi yang terlibat dalam rantai makanan dalam industri makanan dan pangan, terlepas dari ukuran atau kompleksitasnya.

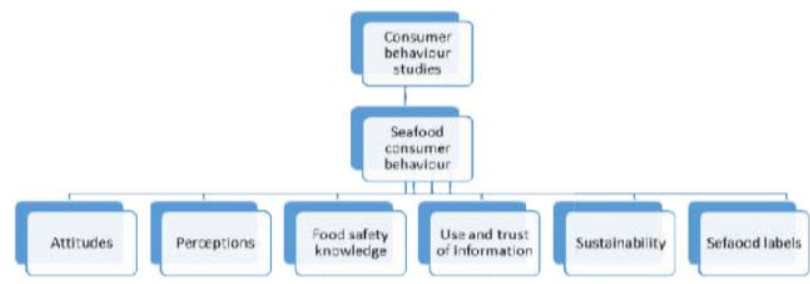

Gambar 2 Studi Perilaku Konsumen terhadap Makanan Laut

(Rahmaniya \& Sekharan, 2018) Makanan laut, kaya asam lemak omega 3, sumber protein tanpa lemak dan nutrisi penting lainnya telah direkomendasikan untuk lebih sering dikonsumsi oleh ahli gizi dan ahli kesehatan. Keamanan yang terkait dengan konsumsi makanan laut merupakan perhatian penting bagi konsumen, menjadikan makanan laut sebagai produk makanan dengan keterlibatan tinggi, dalam kehidupan sehari-hari. Pemasaran makanan laut secara efisien merupakan tantangan karena atribut kualitas dan keamanannya yang spesifik. Sikap, preferensi, dan persepsi konsumen terhadap keamanan makanan laut serta pengetahuan dan informasi konsumen tentang keamanan makanan laut menentukan pembelian makanan laut. Keberlanjutan dan keterlacakan produk makanan laut juga memengaruhi perilaku konsumen terhadapnya. Sikap umum konsumen adalah memberikan perhatian yang besar terhadap aspek kualitas dan keamanan seafood yang mempengaruhi perilaku pembelian mereka. Secara umum, konsumen lebih menyadari kandungan dan efek zat berbahaya dibandingkan nutrisi pada ikan. Upaya dilakukan untuk mendapatkan persepsi strategis makanan laut dari konsumen makanan laut.

(Zugravu Gheorghe \& Turek Rahoveanu, Maria Magdalena; Turek Rahoveanu, 2012), sebagian besar masalah 
keamanan dalam produk makanan berasal dari kontaminasi mikroba dan kimiawi. Kedua bahaya ini harus diukur dan dikendalikan untuk meningkatkan keamanan pasokan pangan. Analisis Bahaya dan Pemrosesan Titik Kontrol Kritis (Hazard Analysis and Critical Control Point Processing / HACCP) membatasi kekhawatiran ini. Prosesor yang menggunakan HACCP harus mengidentifikasi kemungkinan bahaya dan membuat rencana terperinci tentang cara mendeteksi dan menangani bahaya ini. Tujuan utama HAACP melibatkan pencatatan titik kontrol dan memastikan bahwa titik-titik ini disimpan dalam kisaran yang diinginkan.

\section{Usaha Mikro, Kecil dan Menengah (UMKM)}

Berdasarkan Undang Undang Republik Indonesia nomor 20 Tahun 2008 tentang Usaha Mikro, Kecil dan Menengah (UMKM) menyebutkan bahwa kriteria usaha mikro adalah memiliki kekayaan bersih paling banyak Rp50.000.000,o0; usaha kecil adalah memiliki kekayaan bersih lebih dari Rp50.000.000,00 sampai dengan paling banyak Rp500.000.000,00 dan usaha menengah adalah memiliki kekayaan bersih lebih dari Rp500.000.000,00 sampai dengan paling banyak Rp10.000.000.000,00 (Presiden Republik Indonesia, 2008).

Tabel 1. Kriteria UMKM Berdasarkan Aset dan Omset

\begin{tabular}{ccc}
$\begin{array}{c}\text { Ukuran } \\
\text { Usaha }\end{array}$ & Aset & Omset \\
\hline Usaha Mikro & Maksimal Rp 50 juta & $\begin{array}{c}\text { Maksimal Rp } \\
\text { 300 juta }\end{array}$ \\
\hline Usaha Kecil & $>$ Rp 50 juta -500 & $>$ Rp 300 juta - \\
& juta & Rp 2,5 milyar \\
\hline Usaha & $>$ Rp 500 juta - 10 & $>$ Rp 2,5 milyar \\
Menengah & milyar & - Rp 50 milyar \\
\hline Usaha Besar & $>$ Rp 10 milyar & $>$ Rp 50 milyar \\
\hline
\end{tabular}

Sumber: Undang-Undang Republik Indonesia Nomor 20 Tahun 2008

\section{Keranga Penelitian}

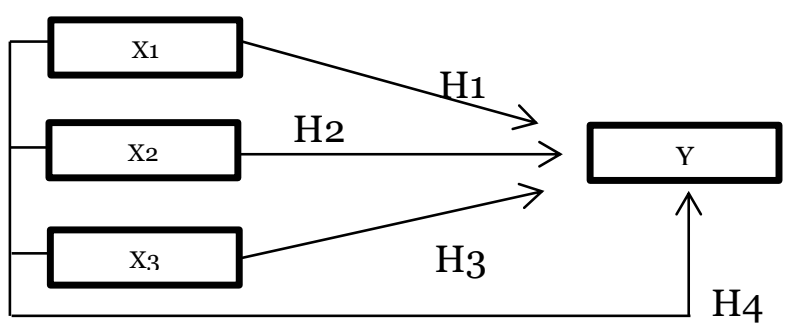

Gambar 3. Kerangka Penelitian

\section{Hipotesis}

H1: Ada pengaruh kualitas produk terhadap keputusan konsumen;

H2: Ada pengaruh harga terhadap keputusan konsumen;

H3: Ada pengaruh food safety terhadap keputusan konsumen;

H4: Ada pengaruh kualitas produk, harga dan food safety terhadap keputusan konsumen;

\section{METODE PENELITIAN}

Populasi dalam penelitian ini adalah seluruh karyawan yang bekerja pada usaha mikro, kecil dan menengah di Kecamatan Panimbang Provinsi Banten. Sampel yang digunakan dalam penelitian adalah purposive sampling dengan jumlah 95 orang. Data primer dengan melakukan observasi lapangan, dokumentasi dan wawancara. Data sekunder bersumber dari Dinas Pariwisata Kabupaten Pandeglang Provinsi Banten Penelitian ini menggunakan metode penelitian kuantitatif dengan analisis uji validitas, reliabilitas, normalitas, uji t, uji $\mathrm{F}$ dan koefisien determinasi.

\section{HASIL PENELITIAN DAN PEMBAHASAN}

(Dinas Kelautan dan Perikanan Provinsi Banten, 2018) Perairan Kabupaten 
Pandeglang di Selat Sunda seluas 1.352,72 km2 dan Perairan Kabupaten Pandeglang di Samudra Indonesia seluas 349,28. Nelayan menangkap ikan dengan menggunakan bagan dan dipengaruhi banyak faktor antara lain: alat tangkap ikan yang digunakan, biaya operasional, ketrampilan anak buah kapal dan cuaca serta persaingan antar nelayan. Tangkapan ikan oleh nelayan disekitar Selat Sunda hingga Perairan Lampung selama beberapa hari, hasilnya dibawa ke Tempat Pelelangan Ikan (TPI) Desa Panimbang Jaya Kecamatan Panimbang. TPI ini memiliki dermaga alam sangat sederhana, kantor TPI sangat minim dan kurang terpelihara dengan baik, logistik solar dari Pertamina berjumlah 2 unit serta minimnya fasilitas cold storage.

Pengasin dapat membeli ikan asin yang sudah masak langsung dari para nelayan dan juga dapat membeli ikan segar $1-20$ ton di TPI ini setiap hari mulai jam 6 hingga 9 pagi sebagai bahan baku pengolah ikan asin. Pengasin juga memiliki persaingan dengan pengasin lainnya yang berasal dari Kecamatan Panimbang maupun Kecamatan lainnya di Kabupaten Pandeglang. Untuk mendapatkan bahan baku ikan ini, pengasin juga bersaing ketat dengan pengecer, distributor dan grosir.

Sebagian besar pengasin masih menggunakan cara tradisional dalam hal penjemuran dengan sinar matahari, penyortiran untuk menentukan kualitas ikan asin baik, sedang dan buruk serta pengemasan.Sebagian besar pengasih menjual produknya kepada para pelanggan tetap yang sudah dikenal baik dan berasal dari Kabupaten Pandeglang. Hanya sebagian kecil pelanggan berasal dari Kota dan Kabupaten Serang, Kota dan Kabupaten Lebak, Kota dan Kabupaten Tangerang, Jakarta dan Bogor.
Tabel 2. Produksi Tangkap dan Budidaya di Kabupaten Pandeglang

\begin{tabular}{cccc}
\hline Tahun & Tangkap & Budidaya & Jumlah \\
\hline 2015 & 68.696 & 105.480 & 174.176 \\
\hline 2016 & 52.443 & 103.449 & 155.892 \\
\hline 2017 & 58.210 .000 & 142.861 .451 & 201.071 .451 \\
\cline { 2 - 4 }
\end{tabular}

Sumber: (Pusat Data Statistik dan Informasi Dinas

Kelautan dan Perikanan Provinsi Banten, 2018)

Tabel 3. Produksi Tangkap dan Budidaya Dalam Rupiah di Kabupaten Pandeglang

\begin{tabular}{cccc}
\hline Tahun & Tangkap & Budidaya & Jumlah \\
\hline 2015 & 933.360 .140 & 124.991 .120 & 1.058 .351 .260 \\
\hline 2016 & 1.232 .620 .809 & 889.208 .031 & $1.322,430,820$ \\
\hline 2017 & 1.413 .656 .281 & 532.485 .028 .801 & 533.898 .685 .082 \\
\hline
\end{tabular}

Sumber: (Pusat Data Statistik dan Informasi Dinas

Kelautan dan Perikanan Provinsi Banten, 2018)

Tabel 4. Produk Domestik Regional Bruto Provinsi Banten (PDRB) Sektor Perikanan di Kabupaten Pandeglang Atas Dasar Harga Berlaku dan Harga Konstan Tahun 20102017 (Juta Rupiah

\begin{tabular}{ccc}
\hline Tahun & Harga Berlaku & Harga Konstan \\
\hline 2015 & 2.526 .159 & 1.799 .643 \\
\hline 2016 & 2.755 .169 & 1.896 .775 \\
\hline 2017 & 3.096 .387 & 1.995 .619 \\
\hline
\end{tabular}

Sumber: (Pusat Data Statistik dan Informasi Dinas Kelautan dan Perikanan Provinsi Banten, 2018)

Tabel 5. Nelayan, Armada, Alat Tangkap dan Rumah Tangga Perikan Kab. Pandeglang

\begin{tabular}{cccc}
\hline Nelayan & Armada & $\begin{array}{c}\text { Alat } \\
\text { tangkap }\end{array}$ & $\begin{array}{c}\text { Rumah Tangga } \\
\text { Perikanan }\end{array}$ \\
\hline 30.336 & 8.567 & 13.817 & 3.277 \\
\hline
\end{tabular}

Sumber: (Pusat Data Statistik dan Informasi Dinas Kelautan dan Perikanan Provinsi Banten, 2018)

Tabel 6. Volume dan Nilai Produk Hasil Perikanan Menurut Pelaku Pemasaran

\begin{tabular}{crrr}
$\begin{array}{c}\text { Pelaku } \\
\text { Pemasaran }\end{array}$ & $\begin{array}{r}\text { Volume } \\
(\mathrm{kg})\end{array}$ & Nilai Beli (Rp) & Nilai Jual \\
\hline Pengumpul & 31.428 & 507.927 .273 & 586.472 .727 \\
\hline $\begin{array}{c}\text { Pedagang } \\
\text { Besar }\end{array}$ & 253.140 & 4.887 .960 .000 & 6.574 .800 .00 \\
\hline Pengecer & 545.973 & 13.321 .119 .966 & 16.316 .503 .683 \\
\hline Jumlah & 830.531 & 18.717 .007 .239 & 23.477 .776 .410 \\
\hline
\end{tabular}

Sumber: (Pusat Data Statistik dan Informasi Dinas Kelautan dan Perikanan Provinsi Banten, 2018)

Rumah tangga perikanan di Kabupaten Pandeglang tahun 2017 berjumlah 2.516 dengan menggunakan penerapan teknologi secara intensif berjumlah 6 dan masih menggunakan cara tradisional berjumlah 60. Jumlah unit cold storage di Kabupaten Pandeglang sangat minim hanya berjumlah 4 unit tahun 2017 dan sangat jauh dari ideal, hal ini karena kurangnya pemerintah provinsi Banten dan 
pemerintah kabupaten Pandeglang dalam mempromosikan sektor perikanan kepada investor asing dan domestik untuk menanamkan modalnya.

Kabupaten Pandeglang memiliki 2.323 unit yang terdiri dari 394 unit pengolahan hasil perikanan dan 1.929 unit pemasaran hasil perikanan. Berdasarkan data dari (Pusat Data Statistik dan Informasi Dinas Kelautan dan Perikanan Provinsi Banten, 2018), jumlah unit pemasaran ikan di Kabupaten Pandeglang berjumlah 1.929 terdiri dari 25 pengumpul, 1.880 pengecer dan 24 pedagang besar atau distributor.

Harga ikan asin dalam rupiah per $\mathrm{kg}$ di Pasar Panimbangjaya Banten adalah sebagai berikut teri nasi 150.000 , teri jenki bulat dan belah 120.000, cumi-cumi 140.000, ikan pete 30.000, ikan layur 60.000 , ikan rebusan banyar 60.000, ikan baji-baji 50.000, ikan kurusi 50.000, ikan mimis tawar 50.000, ikan teri tawar 80.000, ikan lemuru 50.000, ikan peda merah 60.000, ikan peda putih 60.000, ikan rebon 50. .ooo.

\begin{tabular}{|c|c|c|c|}
\hline $\begin{array}{c}\text { Variabel } \\
\text { Demografik }\end{array}$ & Kategori & Jumlah & Persentase \\
\hline \multirow[t]{2}{*}{$\begin{array}{c}\text { Jenis } \\
\text { Kelamin } \\
\end{array}$} & Laki-Laki & 55 & 58,51 \\
\hline & Wanita & 39 & 41,49 \\
\hline \multirow[t]{3}{*}{ Umur } & $17-30$ & 29 & 30,85 \\
\hline & $31-50$ & 47 & 50,00 \\
\hline & $>51$ & 18 & 19,15 \\
\hline \multirow[t]{3}{*}{ Pendidikan } & $\begin{array}{c}\text { SD, SMP dan } \\
\text { SMA }\end{array}$ & 76 & 80,85 \\
\hline & $\begin{array}{c}\text { Diploma dan } \\
\text { S1 } \\
\end{array}$ & 18 & 19,15 \\
\hline & $\mathrm{S} 2$ dan $\mathrm{S} 3$ & $\begin{array}{c}\text { Tidak } \\
\text { ada }\end{array}$ & 00,00 \\
\hline \multirow[t]{3}{*}{$\begin{array}{l}\text { Tempat } \\
\text { Tinggal }\end{array}$} & $\begin{array}{c}\text { Kabupaten } \\
\text { Pandeglang }\end{array}$ & 48 & 51,06 \\
\hline & $\begin{array}{c}\text { Kota dan } \\
\text { Kabupaten } \\
\text { Serang }\end{array}$ & 18 & 19,15 \\
\hline & $\begin{array}{c}\text { Kota dan } \\
\text { Kabupaten } \\
\text { Tangerang }\end{array}$ & 12 & 12,77 \\
\hline
\end{tabular}

\begin{tabular}{ccc}
\hline Jakarta & 11 & 11,70 \\
\hline Kota dan & 5 & 0,532 \\
$\begin{array}{c}\text { Kabupaten } \\
\text { Bogor }\end{array}$ & & \\
\hline
\end{tabular}

Sumber: data Diolah oleh Peneliti

\section{Uji Validitas}

Tabel 6. Ringakasan Uji Validitas

\begin{tabular}{|l|r|r|r|r|}
\hline Item & $\mathrm{X} 1$ & $\mathrm{X} 2$ & $\mathrm{X} 3$ & $\mathrm{Y}$ \\
\hline Item 1 & .832 & .341 & .855 & .844 \\
\hline Item 2 & .880 & .519 & .835 & .715 \\
\hline Item 3 & .918 & .818 & .726 & .860 \\
\hline Item 4 & .872 & .836 & .712 & .765 \\
\hline
\end{tabular}

Sumber: Data Diolah Peneliti dengan SPSS Version 20

Berdasarkan table 7 diperoleh seluruh item dinyatakan valid karena nilai pearson correlation atau $\mathrm{r}$ hitung $\leq \mathrm{r}$ tabel atau 0,2006 berarti valid dan penelitian ini dapat dilanjutnya ke tahap selanjutnya.

\section{Uji Reliabilitas}

Tabel 8 Ringakasan Uji Realiabilitas

\begin{tabular}{|l|r|r|r|r|}
\hline Uji Reliabilitas & $\mathrm{X} 1$ & $\mathrm{X} 2$ & $\mathrm{X} 3$ & $\mathrm{Y}$ \\
\hline Cronbach Alpha & .896 & .527 & .789 & .807 \\
\hline
\end{tabular}

Sumber: Data Diolah Peneliti dengan SPSS Version 20

Berdasarkan table 8 diperoleh seluruh item dinyatakan reliable atau konsisten karena nilai cronbach's alpha $\geq \mathrm{r}$ tabel atau 0,2006 berarti konsisten dan penelitian ini dapat dilanjutnya ke tahap selanjutnya.

\section{Uji Normalitas}

Berdasarkan tabel 9, 10 dan 11 uji normalitas diperoleh nilai signifikansi $\geq$ o,05 maka dapat dikatakan bahwa nilai berdistribusi normal.

Tabel 9. Uji Normalitas Kualitas Produk terhadap Keputusan Konsumen

One-Sample Kolmogorov-Smirnov Test

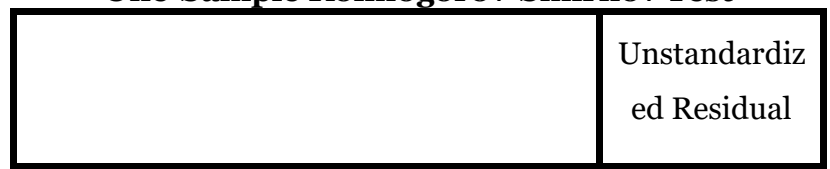




\begin{tabular}{|ll|r|}
\hline $\mathrm{N}$ & & 95 \\
& Mean & oE-7 \\
Normal Parameters & a,b & Std. \\
& Deviation & 1.24192223 \\
& Absolute & .235 \\
Most Extreme & Positive & .235 \\
Differences & Negative & -.218 \\
& & 2.287 \\
Kolmogorov-Smirnov Z & & .106 \\
Asymp. Sig. (2-tailed) & & \\
\hline
\end{tabular}

a. Test distribution is Normal.

b. Calculated from data.

Sumber: Data Diolah Oleh Peneliti dengan SPSS

Tabel 10. Uji Normalitas Harga terhadap Keputusan Konsumen

One-Sample Kolmogorov-Smirnov Test

\begin{tabular}{|ll|r|}
\hline & & $\begin{array}{r}\text { Unstandardiz } \\
\text { ed Residual }\end{array}$ \\
\hline $\mathrm{N}$ & Mean & 95 \\
& oE-7 \\
Normal Parameters & \\
& Std. & 1.52372832 \\
Most Extreme & Deviation & .167 \\
Differences & Absolute & .167 \\
Kolmogorov-Smirnov Z & & -.101 \\
Asymp. Sig. (2-tailed) & & 1.625 \\
\hline
\end{tabular}

a. Test distribution is Normal.

b. Calculated from data.

Sumber: Data Diolah Oleh Peneliti dengan SPSS

Tabel 11. Uji Normalitas Food Safety terhadap Keputusan Konsumen

One-Sample Kolmogorov-Smirnov Test

\begin{tabular}{|c|c|c|}
\hline & & $\begin{array}{l}\text { Unstandardiz } \\
\text { ed Residual }\end{array}$ \\
\hline $\mathrm{N}$ & & 95 \\
\hline Normal Parameters ${ }^{\mathrm{a}, \mathrm{b}}$ & Mean & oE-7 \\
\hline
\end{tabular}

\begin{tabular}{|ll|r|} 
& Std. & \\
& Deviation & 1.40143051 \\
Most Extreme & Absolute & .216 \\
Differences & Positive & .216 \\
& Negative & -.121 \\
Kolmogorov-Smirnov Z & & 2.103 \\
Asymp. Sig. (2-tailed) & & .104 \\
\hline
\end{tabular}

a. Test distribution is Normal.

b. Calculated from data.

Sumber: Data Diolah Oleh Peneliti dengan SPSS

\section{Uji T}

Tabel 12. Uji T Kualitas Produk terhadap Keputusan Konsumen

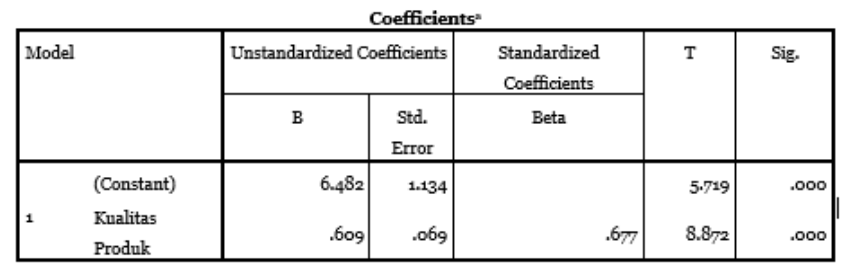

a. Dependent Variable: Keputusan Konsumen

Sumber: Data Diolah Oleh Peneliti dengan SPSS

Tabel 13. Uji T Harga terhadap Keputusan Konsumen

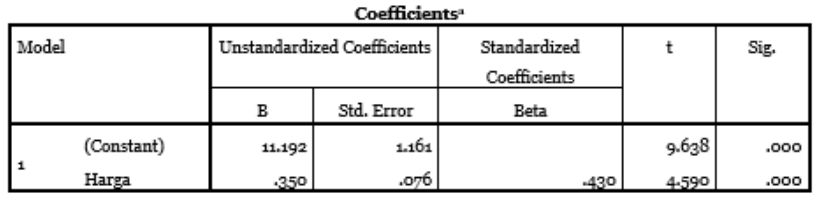

a. Dependent Variable: Keputusan Konsumen

Sumber: Data Diolah Oleh Peneliti dengan SPSS

Tabel 13. Uji T Food Safety terhadap Keputusan Konsumen

\begin{tabular}{|c|c|c|c|c|c|c|}
\hline \multirow{3}{*}{\multicolumn{2}{|c|}{ Model }} & \multicolumn{3}{|c|}{ Coefficients $^{3}$} & \multirow{3}{*}{$t$} & \multirow{3}{*}{ Sig. } \\
\hline & & \multicolumn{2}{|c|}{$\begin{array}{l}\text { Unstandardized } \\
\text { Coefficients }\end{array}$} & \multirow{2}{*}{$\begin{array}{c}\text { Standardized } \\
\text { Coefficients } \\
\text { Beta } \\
\end{array}$} & & \\
\hline & & B & Std. Error & & & \\
\hline & (Constant) & 7.990 & 1.319 & & 6.055 & .000 \\
\hline 1 & Food Safety & .526 & .081 & .557 & 6.469 & .000 \\
\hline
\end{tabular}

a. Dependent Variable: Keputusan Konsumen

Sumber: Data Diolah Oleh Peneliti dengan SPSS

Berdasarkan table 12, 13, dan 14 uji t diperoleh nilai $t$ hitung $\geq t$ table $(1,9860)$ dan signifikansi hitung $(0,00) \leq$ signifikansi table (0,05), maka dapat diartikan ada pengaruh yang signifikan kualiatas produk terhadap keputusan konsumen, ada pengaruh harga terhadap keputusan 
konsumen dan ada pengaruh food safety terhadap keputusan konsumen.

\section{Uji F}

Tabel 15. Uji F Kualitas Produk, Harga dan Food Safety terhadap Keputusan Konsumen

\begin{tabular}{|ll|r|r|r|r|c|}
\hline \multicolumn{1}{|l|}{ Model } & \multicolumn{1}{c|}{$\begin{array}{c}\text { Sum of } \\
\text { Squares }\end{array}$} & \multicolumn{1}{c|}{ df } & \multicolumn{1}{c|}{$\begin{array}{c}\text { Mean } \\
\text { Square }\end{array}$} & F & Sig. \\
\hline \multirow{2}{*}{1} & Regression & 137.057 & 3 & 45.686 & 31.826 & $.000^{\mathrm{b}}$ \\
& Residual & 130.627 & 91 & 1.435 & & \\
& Total & 267.684 & 94 & & & \\
\hline
\end{tabular}

a. Dependent Variable: Keputusan Konsumen

b. Predictors: (Constant), Food Safety, Harga, Kualitas Produk

Sumber: Data Diolah Oleh Peneliti dengan SPSS

Berdasarkan table 15 diperoleh nilai F hitung $>\mathrm{F}$ table dan nilai signifikan 0,00 $<0,05$ dapat diartikan terdapat pengaruh yang signifikan kualitas produk, harga dan food safety terhadap keputusan konsumen.

\section{R Square}

Berdasarkan tabel 16, 17 dan 18 diperoleh koefisien determinasi kualitas produk terhadap keputusan konsumen sebesar 0.458 atau variabel kualitas harga senilai 45,80\% lebih besar apabila dibandingkan dengan variabel food safety senilai $31 \%$ dan variabel harga senilai $17,6 \%$.

Tabel 16. Koefisien Determinasi Kualitas Produk terhadap Keputusan Konsumen

Model Summary

\begin{tabular}{|l|c|r|r|r|}
\hline Model & $\mathrm{R}$ & $\begin{array}{c}\mathrm{R} \\
\text { Square }\end{array}$ & $\begin{array}{c}\text { Adjusted R } \\
\text { Square }\end{array}$ & $\begin{array}{c}\text { Std. Error of } \\
\text { the Estimate }\end{array}$ \\
\hline 1 & $.677^{\mathrm{a}}$ & .458 & .453 & 1.249 \\
\hline
\end{tabular}

a. Predictors: (Constant), Kualitas Produk

Tabel 17. Koefisien Determinasi Harga terhadap Keputusan Konsumen

\begin{tabular}{|l|c|r|r|r|}
\hline Model & $\mathrm{R}$ & $\mathrm{R}$ & $\begin{array}{c}\text { Adjusted R } \\
\text { Square }\end{array}$ & $\begin{array}{c}\text { Std. Error of } \\
\text { the Estimate }\end{array}$ \\
\hline 1 & $.430^{\mathrm{a}}$ & .185 & .176 & 1.532 \\
\hline
\end{tabular}

a. Predictors: (Constant), Harga

Tabel 18. Koefisien Determinasi Food safety terhadap Keputusan Konsumen

Model Summary

\begin{tabular}{|l|c|c|r|r|}
\hline Model & $\mathrm{R}$ & $\begin{array}{c}\mathrm{R} \\
\text { Square }\end{array}$ & $\begin{array}{c}\text { Adjusted R } \\
\text { Square }\end{array}$ & $\begin{array}{c}\text { Std. Error of } \\
\text { the Estimate }\end{array}$ \\
\hline 1 & $.557^{\mathrm{a}}$ & .310 & .303 & 1.409 \\
\hline
\end{tabular}

a. Predictors: (Constant), Food Safety

\section{Pembahasan}

\section{Kualitas Produk terhadap Keputusan Konsumen}

Hipotesis pertama diperoleh nilai $\mathrm{t}$ hitung $(8,872) \geq \mathrm{t}$ tabel $(1,986)$ dapat diartikan bahwa ada pengaruh yang signifikan kualitas produk terhadap keputusan konsumen. Semakin baik kualitas produk, maka semakin tinggi keputusan konsumen untuk membeli produk ikan asin Panimbang Banten. Indikator produk berkualitas yang paling dominan adalah rasa apabila dibandingkan indikator lainnya seperti warna, bau dan metode proses ikan asin.

Penelitian ini mendukung penelitian sebelumnya yang dilakukan oleh (Chotimarkorn, 2014) dengan judul "Quality Changes of Anchovy (Stolephorusheterolobus) Under Refrigerated Storage of Different Practical Industrial Methods in Thailand" mengatakan bahwa perubahan kualitas otot ikan teri (Stolephorus heterolobus) selama 7 hari ditemukan pada otot ikan teri selama penyimpanan lemari es menghasilkan pemeliharaan kualitas sensorik yang lebih baik, kontrol aktivitas mikroba yang lebih baik, dan perlambatan mekanisme degradasi biokimia. Penyimpanan ikan teri dengan es dalam lemari es memungkinkan 
pemeliharaan kualitas yang lebih baik dan meningkatkan umur simpan ikan hingga 6 hari. Penelitian ini mendukung penelitian sebelumnya yang dilakukan oleh (Rahmaniya \& Sekharan, 2018) dengan judul "Consumer Behaviour Towards Seafood and Seafood safety" yang mengatakan bahwa Konsumen sangat positif tentang label kualitas produk. Memastikan mereka tentang kualitas makanan laut dengan label membuat mereka lebih percaya diri dalam membeli makanan laut. Memberikan jaminan tentang kualitas makanan laut dengan sertifikasi kualitas dan sistem ketertelusuran akan menyampaikan kesegaran dan keamanan produk. Penyampaian jaminan seafood pada label melaksanakan studi perilaku konsumen dan kesadaran konsumen tentang keamanan seafood

\section{Harga terhadap Keputusan Konsumen}

Hipotesis kedua diperoleh nilai $\mathrm{t}$ hitung $(4,590) \geq \mathrm{t}$ tabel $(1,986)$ dapat diartikan bahwa ada pengaruh yang signifikan harga terhadap keputusan konsumen. Semakin banyak pilihan harga dari para pengasin, maka semakin tinggi keputusan konsumen memilih dan membeli produk ikan asin Panimbang Banten. Indikator harga yang paling dominan adalah biaya pembelian bahan baku apabila dibandingkan indikator lainnya seperti biaya tenaga kerja dan persaingan harga.

Penelitian ini mendukung penelitian sebelumnya yang dilakukan oleh (A. et al., 2015) dengan judul "The Study of Consumption Behaviors and Factors Affecting Decision to Purchase Fishery Products of Consumers in the North and Northeast of Thailand" yang mengatakan bahwa penetapan harga adalah faktor paling kritis yang mempengaruhi keputusan untuk membeli produk perikanan. Penelitian ini mendukung penelitian sebelumnya yang dilakukan oleh (Mayangsari et al., 2021) dengan judul "Analysis of Society's Fish Consumption in Cilaku Cianjur District Area" yang mengatakan bahwa faktor yang paling mempengaruhi keputusan pembelian ikan adalah harga ikan, budidaya, keluarga konsumen, dan kualitas ikan.

\section{Food Safety terhadap Keputusan Konsumen}

Hipotesis ketiga diperoleh nilai $\mathrm{t}$ hitung $(6,469) \geq \mathrm{t}$ tabel $(1,986)$ dapat diartikan bahwa ada pengaruh yang signifikan food safety terhadap keputusan konsumen. Semakin aman produk ikan asin dari kontaminasi bahan-bahan kimia, maka semakin meningkat keputusan konsumen membeli ikan asin Panimbang Banten. Indikator yang paling rendah adalah tidak adanya label food safety apabila dibandingkan indikator lainnya seperti kontaminasi bahan-bahan kimia, garam dan mikrroba.

Penelitian ini mendukung penelitian sebelumnya yang dilakukan oleh (Rahmaniya \& Sekharan, 2018) dengan judul "Consumer Behaviour Towards Seafood and Seafood safety" yang mengatakan bahwa strategi untuk mengurangi persepsi risiko konsumen makanan laut Memberikan informasi yang akurat secara ilmiah dan dapat dipercaya tentang risiko fisik makanan laut akan membantu mengurangi persepsi risiko makanan laut pada konsumen. Konflik gizi toksikologi makanan laut menunjukkan bahwa konsumsi makanan laut dipersepsikan memiliki manfaat kesehatan yang relatif tinggi dibandingkan dengan risiko keamanan makanan laut. Dengan memberikan pemahaman yang jelas kepada konsumen tentang konflik toksikologi nutrisi pada seafood konsumen akan lebih 
terpacu untuk mengkonsumsi ikan dan produk seafood. Penelitian ini mendukung penelitian sebelumnya yang dilakukan oleh (Liewin \& Genoveva, 2019) dengan judul "The Role of Purchase Intention on International Food Brands during Covid-19 Pandemic" dan hasil penelitian menunjukkan bahwa keamanan pangan, kualitas pangan dan lingkungan berpengaruh signifikan terhadap keputusan konsumen selama pandemi Covid-19.

\section{Kualitas Produk, Harga dan Food Safety terhadap Keputusan Konsumen}

Hipotesis keempat diperoleh nilai $\mathrm{F}$ hitung $(31,826) \geq F$ tabel $(2,720)$ dapat diartikan bahwa ada pengaruh yang signifikan kualitas produk, harga dan food safety terhadap keputusan konsumen. Semakin baik kualitas produk, persaingan harga kompetitif dan aman dari kontamina, maka semakin tinggi keputusan konsumen untuk membeli produk ikan teri Panimbang Banten. Hal ini menunjukkan bahwa keputusan konsumen untuk membeli ikan asin Panimbang Banten banyak faktorfaktor yang menentukan antara lain: kualitas produk, harga dan food safety.

Penelitian ini mendukung penelitian sebelumnya yang dilakukan oleh (Liewin \& Genoveva, 2019) dengan judul "The Role of Purchase Intention on International Food Brands during Covid-19 Pandemic" dan hasil penelitian menunjukkan bahwa food safety pangan, kualitas pangan dan lingkungan berpengaruh signifikan terhadap keputusan konsumen selama pandemi Covid-19.

\section{Kesimpulan}

Keputusan konsumen dipengaruhi secara signifikan oleh kualitas produk.
Semakin baik kualitas produk, maka semakin tinggi keputusan konsumen untuk membeli produk ikan asin Panimbang Banten. Indikator produk berkualitas yang paling dominan adalah rasa apabila dibandingkan indikator lainnya seperti warna, bau dan metode proses ikan asin. Keputusan konsumen dipengaruhi secara signifikan oleh Harga. Semakin banyak pilihan harga dari para pengasin, maka semakin tinggi keputusan konsumen memilih dan membeli produk ikan asin Panimbang Banten. Indikator harga yang paling dominan adalah biaya pembelian bahan baku apabila dibandingkan indikator lainnya seperti biaya tenaga kerja dan persaingan harga. Keputusan konsumen dipengaruhi secara signifikan oleh food safety. Semakin aman produk ikan asin dari kontaminasi bahan-bahan kimia, maka semakin meningkat keputusan konsumen membeli ikan asin Panimbang Banten. Indikator yang paling rendah adalah tidak adanya label food safety apabila dibandingkan indikator lainnya seperti kontaminasi bahan-bahan kimia, garam dan mikrroba. Semakin baik kualitas produk, persaingan harga kompetitif dan aman dari kontamina, maka semakin tinggi keputusan konsumen untuk membeli produk ikan teri Panimbang Banten. Hal ini menunjukkan bahwa keputusan konsumen untuk membeli ikan asin Panimbang Banten banyak faktorfaktor yang menentukan antara lain: kualitas produk, harga dan food safety. Berdasarkan nilai koefisien determinasi diperoleh variabel kualitas produk lebih berpengaruh terahadp keputusan konsumen apabila dibandingkan dengan variabel harga dan food safety.

\section{Daftar Pustaka}

A., K., P., P., \& J., B. (2015). The Study of Consumption Behaviors and Factors 
Affecting Decision to Purchase Fishery Products of Consumers in the North and Northeast of Thailand. International Food Research Journal, 22(6), $\quad 2670-2678$. http://www.ifrj.upm.edu.my/22 (o6) 2015/(57).pdf

Baldwin, R., \& Harrigan, J. (2011). Zeros, Quality, and Space: Trade Theory and Trade Evidence. American Economic Journal, 3(2), 60-88. https://doi.org/10.1257/mic.3.2.60

Bremner, H. A. (2003). Safety and Quality Issues in Fish Processing. In H. A. Bremner (Ed.), Journal of Aquatic Food Product Technology (1st ed., Vol. 12, Issue 3). WoodheadPublishingLimited. https://doi.org/10.1300/Jo30v12no3_ 08

Chotimarkorn, C. (2014). Quality Changes of Anchovy (Stolephorusheterolobus) Under Refrigerated Storage of Different Practical Industrial Methods in Thailand. Journal of Food Science and Technology, 51(2), 285-293. https://doi.org/10.1007/s13197-0110505-y

Dinas Kelautan dan Perikanan Provinsi Banten. (2018). Kelautan dan Perikanan Dalam Angka 2018 (Suyitno (ed.); 1st ed.). Dinas Kelauatan dan Perikanan Provinsi Banten.

Fajgelbaum, P., Grossman, G. M., \& Helpman, E. (2011). Income distribution, product quality, and international trade. Journal of Political Economy, 119(4), 721-765. https://doi.org/10.1086/662628

Food and Agriculture Organization. (2020). Food and Agriculture Organization Assuring Food Safety and Quality: Guidelines for Strengthening National Food Control Systems (FAO (ed.); 1st ed.). FAO.

Haghiri, M. (2016). Consumer Choice between Food Safety and FoodQuality:
The Case of Farm-Raised Atlantic. Foods, 5(2), 1-11. https://doi.org/10.3390/foods502002 2

Hidayat, W. W., Soehardi, S., Prasetyo, E. T., \& Husadha, C. (2021). Implications of Covid-19 Pandemic on MSMEs to Economy, Society: Case in the Country of Indonesia. Systematic Reviews in Pharmacy, 12(4), 71-78. https://doi.org/https://www.sysrevph arm.org/articles/implications-ofcovid19-pandemic-on-msmes-toeconomy-society-case-in-the-countryof-indonesia.pdf

Iso Indonesia Center. (2018). ISO 22000:2018 Sistem Manajemen Keamanan Pangan. Isoindonesiacenter.Com.

Kotler, P., \& Keller, K. L. (2012). Marketing Management (E. Svensen (ed.); 14th ed.). Pearson Education, Inc. http://eprints.stiperdharmawacana.ac. id/24/1/\%5BPhillip_Kotler\%5D_Mark eting_Management_14th_Edition\%28 BookFi\%29.pdf

Liewin, S. L., \& Genoveva, G. (2019). the Role of Purchase Intention on Mediating the Relationship. The 4th International Conference on Family Business and Entrepreneurship, 2(February), 33-39. http://ejournal.president.ac.id/presunivojs/in dex.php/ICFBE/article/view/1374

Maina, T. W., \& Ndolo, J. (2019). To Buy Online or Not? An Analysis of Online Consumer Decision Making. International Journal of Science and Business, 3(3), 135-140. https://doi.org/10.5281/zenodo.26544 oo

Mayangsari, N., Rizal, A., Supriadi, D., \& Suryana, A. A. H. (2021). Analysis of Society's Fish Consumption in Cilaku Cianjur District Area. Asian Journal of Fisheries and Aquatic Research, 11(4), 43-50. 
https://doi.org/10.9734/ajfar/2021/v1 $1 \mathrm{i} 430212$

Oke, A. O., Kamolshotiros, P., Popoola, O. Y., Ajagbe, M. A., \& Olujobi, O. J. (2016). Consumer behavior towards decision making and loyalty to particular brands. International Review of Management and Marketing, 6(4), 43-52.

Pogorelova, E. V., Yakhneeva, I. V., Agafonova, A. N., \& Prokubovskaya, A. O. (2016). Marketing Mix for ECommerce. International Journal of Environmental and Science Education, 11(14), 6744-6759. https://papers.ssrn.com/sol3/papers.c fm?abstract id $=2848818$

Presiden Republik Indonesia. (2008). Undang-Undang Republik Indonesia Nomor 20 Tahun 2008 (Kementerian Hukum dan HAM (ed.); 1st ed., Issue 1). Kementerian Hukum dan HAM. https://www.ojk.go.id/sustainablefinance/id/peraturan/undangundang/Documents/Undang-Undang Nomor 20 Tahun 2008 Tentang Usaha Mikro, Kecil, dan Menengah.pdf

Pusat Data Statistik dan Informasi Dinas Kelautan dan Perikanan Provinsi Banten. (2018). Kelautan dan Perikanan Dalam Angka 2018 (Suyitno (ed.); 1st ed.). Dinas Kelauatan dan Perikanan Provinsi Banten. https://dmsppid.bantenprov.go.id/upl oad/dms/37/2018.pdf

Rahmaniya, N., \& Sekharan, M. (2018). Consumer Behaviour Towards Seafood and Seafood safety. International Journal of Current Advanced Research, $\quad 7(1), \quad 8727-8736$. https://doi.org/http://dx.doi.org/10.2 4327/ijcar.2018.8736.1417

Soehardi, S. (2021). Model Peningkatan Volume Penjualan Melalui Kualitas Produk, Kualitas Pelayanan Dan Loyalitas Kopi Golda. Jurnal
Manajemen Strategi Dan Aplikasi Bisnis, 4(2), 353-360. https://doi.org/http://ejournal.imperi uminstitute.org/index.php/JMSAB/art icle/view/398

Stankevich, A. (2017). Explaining the Consumer Decision-Making Process: Critical Literature Review. Journal of International Business Research and Marketing, 2(6), 7-14. https://doi.org/10.18775/jibrm.18498558.2015.26.3001

Zugravu Gheorghe, A., \& Turek Rahoveanu, Maria Magdalena; Turek Rahoveanu, A. (2012). The Safety of Fishery Products. In A. Zugravu Gheorghe \& A. Turek Rahoveanu, Maria Magdalena; Turek Rahoveanu (Eds.), 3rd International Symposium "Agrarian Economy and Rural Development Realities and Perspectives for Romania”, Bucharest (pp. 387-394). The Research Institute for Agricultural Economy andRural Development (ICEADR), Bucharest, https://doi.org/http://hdl.handle.net/ 10419/76846 